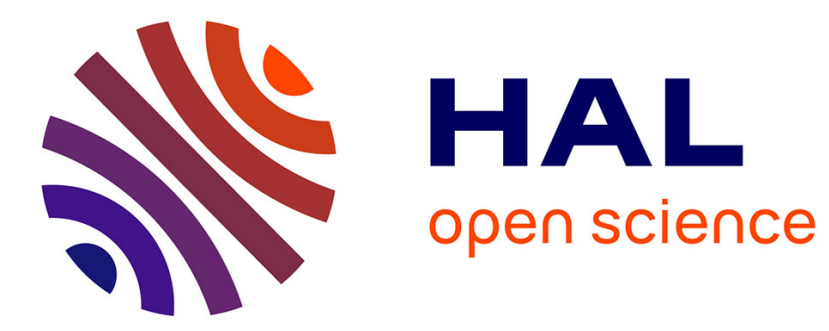

\title{
Anthropogenic effects on subsurface temperature in Bangkok
}

\author{
M. Taniguchi
}

\section{To cite this version:}

M. Taniguchi. Anthropogenic effects on subsurface temperature in Bangkok. Climate of the Past Discussions, 2006, 2 (5), pp.831-846. hal-00298150

\section{HAL Id: hal-00298150 \\ https://hal.science/hal-00298150}

Submitted on 22 Sep 2006

HAL is a multi-disciplinary open access archive for the deposit and dissemination of scientific research documents, whether they are published or not. The documents may come from teaching and research institutions in France or abroad, or from public or private research centers.
L'archive ouverte pluridisciplinaire HAL, est destinée au dépôt et à la diffusion de documents scientifiques de niveau recherche, publiés ou non, émanant des établissements d'enseignement et de recherche français ou étrangers, des laboratoires publics ou privés. 
Clim. Past Discuss., 2, 831-846, 2006 www.clim-past-discuss.net/2/831/2006/ (C) Author(s) 2006. This work is licensed under a Creative Commons License.

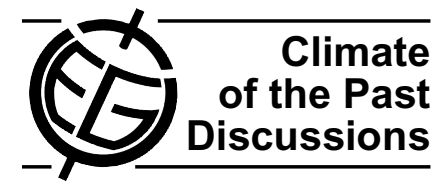

2, 831-846, 2006

Climate of the Past Discussions is the access reviewed discussion forum of Climate of the Past

\section{Anthropogenic effects on subsurface temperature in Bangkok}

\section{Taniguchi}

Research Institute for Humanity and Nature, Kyoto 603-8047, Japan

Received: 1 September 2006 - Accepted: 16 September 2006 - Published: 22 September 2006

Correspondence to: M. Taniguchi (makoto@ chikyu.ac.jp)

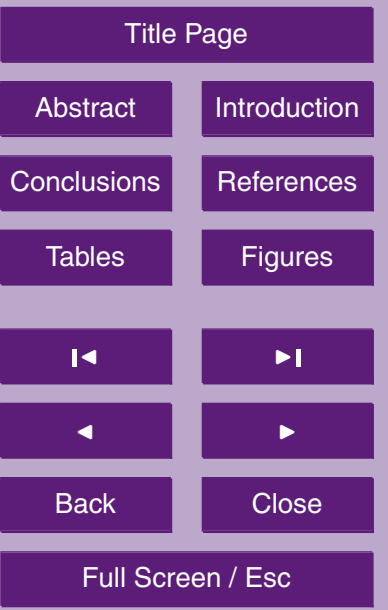

Printer-friendly Version

Interactive Discussion 


\section{Abstract}

Subsurface temperatures in Bangkok, where population and density increase rapidly, were analyzed to evaluate the effects of surface warming due to urbanization. The magnitude of surface warming evaluated from subsurface temperature in Bangkok was

$51.7^{\circ} \mathrm{C}$ which agreed with meteorological data during the last 50 years. The depth apart from steady thermal gradient, which shows an indicator of the magnitude of surface warming due to additional heat from urbanization, was deeper at the center of the city than in the suburb areas of Bangkok. In order to separate surface warming effects into global warming effect and urbanization effect, analyses of subsurface temperature

have been done depending on the distance from the city center. The results show that the expansion of urbanization in Bangkok reaches up to $80 \mathrm{~km}$ from the city center.

\section{Introduction}

Heat island effect on subsurface temperature due to urbanization is one of the global environmental issues because population and density in cities increase rapidly all over the world, particularly in many Asian cities such as Bangkok. The main concern from an environmental point of view is that the current urban transition is occurring much faster than ever before. The greater speed and numbers of this transition impose on Asia a much greater sense of urgency to identify and address the problems this transition brings.

20 Although global warming is considered a serious contemporary global environmental issue, the discussion of the phenomena is limited to above-ground issues. However, subsurface temperatures are also affected by surface warming (Huang et al., 2000). In addition, the "heat island effect" due to urbanization creates subsurface thermal contamination in many cities (Taniguchi et al., 2003). The increased rate of surface and subsurface temperature in cities is thus caused by these combined effects.

Subsurface temperature is used to reconstruct past climate change because the

\section{2, 831-846, 2006}

Anthropogenic effects

M. Taniguchi

\section{Title Page}

Abstract Introduction

Conclusions References

Tables Figures

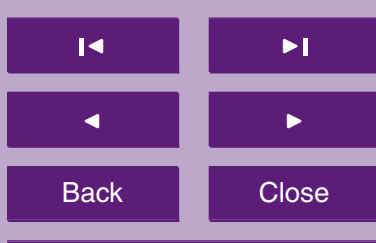

Full Screen / Esc

Printer-friendly Version

Interactive Discussion 
signature of changes in ground surface temperature is preserved in the subsurface thermal regime (Birch, 1948, Lachenbruch and Marshall, 1986, Beck, 1982; Chapman and Harris, 1993, Beltrami et al., 1995, Bodri and Cermak, 1998, Harris and Chapman, 1997; Pollack et al., 1998; Huang et al., 2000, Taniguchi et al., 2003). Recent air 5 temperature in cities is increased by global warming and heat island effects due to urbanization. Studies on the effects of additional heat from urban area on subsurface temperature are limited, but have been done in some urbanized areas in Europe (Bodri and Cermak, 1999) and in Asia (Okubo et al., 2003).

However, previous studies of the effects of surface warming due to urbanization on 10 subsurface thermal environment are limited to studies within local areas (Ferguson and Woodbury, 2004). Subsurface temperature can tell us the heat island effect due to urbanization without meteorological data, however few studies have been done. The purposes of this study are to compare the subsurface temperature in the city and in the suburb areas with distance from the city center as a function, to separate surface warming effects into global warming effect and heat island effect, and to evaluate the development of heat island due to urbanization by using subsurface temperature.

\section{Method and study area}

The study area and locations of boreholes are shown in Fig. 1. The topography in the coastal city of Bangkok is characterized by alluvial plain, and surface geology is an al20 luvium underlain by diluvial formation which consists of main unconfined and confined aquifers. There are three main aquifers in Bangkok. The depth of each aquifer range from $100 \mathrm{~m}$ (Phra Pradacng aquifer) and $150 \mathrm{~m}$ (Nakhon Luang aquifer) to $200 \mathrm{~m}$ (Nonthaburi aquifer). Hydrogeology of Bangkok basin is described in detail by Sanford and Buapeng (1996).

The average annual rainfall in this study area of Thailand is about 900 to $1400 \mathrm{~mm} /$ year. Due to its location in the tropics, temperatures are uniform throughout the year with very little seasonal variation around the mean of $28^{\circ} \mathrm{C}$. The average

Anthropogenic effects

M. Taniguchi

\section{Title Page}

Abstract Introduction

Conclusions References

Tables Figures

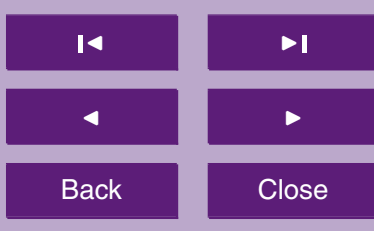

Full Screen / Esc

Printer-friendly Version

Interactive Discussion 
temperature during the hottest month (April) is about $32^{\circ} \mathrm{C}$ and the average temperature during the coolest month (December) is about $25^{\circ} \mathrm{C}$.

Borehole temperatures were measured at $1 \mathrm{~m}$ depth interval in 18 boreholes in Bangkok on June 2006, by means of thermistor thermometers which can read temper5 ature at $0.01^{\circ} \mathrm{C}$ resolution. The boreholes are located in whole basin which includes groundwater recharge area and groundwater discharge area. The depths and diameter of those boreholes are 55-437 $\mathrm{m}$ and $10-30 \mathrm{~cm}$, respectively, therefore no thermal free convection is expected. The logged boreholes are cased, and the drilling had been mostly done before the 1980s. Thus, the water temperatures in boreholes represent

the temperature of groundwater surrounding the boreholes. General geothermal gradients in the study areas are estimated to be $0.040^{\circ} \mathrm{C} / \mathrm{m}$ in Bangkok (Yamano, personal communication, 2006).

\section{Subsurface temperature in city and suburb area of Bangkok}

All temperature-depth profiles observed in Bangkok are shown in Fig. 2. As can be 15 seen from Fig. 2, there is a variability in the profiles. One of the reasons of this variability in temperature-depth profiles is the effect of regional groundwater flow (Taniguchi et al., 1999). According to the Domenico and Palciauskas (1973), temperature-depth profiles with downward water fluxes in recharge areas are concave, and those with upward fluxes in discharge area are convex, though the temperature gradient is constant

without vertical water flow. Subsurface temperature itself is higher in the discharge area than in the recharge area of the groundwater flow system (Taniguchi et al., 1999). The colder profiles are located in the recharge area, and warmer profiles are in the discharge area (Taniguchi et al., 1999, and Taniguchi and Uemura, 2005). Although the temperature-depth profiles varied in a wide range in the city, synthesizing these data in-

cluding recharge and discharge areas can tell us the average subsurface temperature profiles in the city.

The averages of whole temperature-depth profiles observed in Bangkok with stan-

2, 831-846, 2006

Anthropogenic effects

M. Taniguchi

Title Page

Abstract Introduction

Conclusions References

Tables Figures

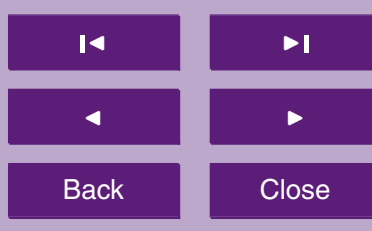

Full Screen / Esc

Printer-friendly Version

Interactive Discussion 
dard deviations and regional geothermal gradients are also shown in Fig. 2. The averaged temperature-depth profile shows the evidence of the surface warming. The difference of extrapolated surface temperature between observed temperature and geothermal gradient is estimated to be $1.7^{\circ} \mathrm{C}$ in Bangkok.

Air temperature records in two meteorological stations $A$ and $B$ in Fig. 1 are shown in Fig. 3. As can be seen from Fig. 3, air temperature increased by $1.64^{\circ} \mathrm{C} / 50 \mathrm{y}$ $\left(R^{2}=0.631\right)$ at $A$, the center of Bangkok, and does not change at $B$, located about $120 \mathrm{~km}$ north from the city center. According to the analyses of global trends of air temperature change by Hansen and Lebendeff (1987), the magnitude of global warm10 ing is about $0.5^{\circ} \mathrm{C} / 100 \mathrm{y}$. The estimated increase in surface temperature from borehole temperature by Huang et al. (2000) is also about $0.5^{\circ} \mathrm{C} / 100 \mathrm{y}$. Thus the increased air temperature in the city center includes not only global warming but also other factors. Bangkok was developed and urbanized rapidly during the last century in particular after World War II. Therefore, the most reasonable explanation for the increase in air temperature more than global warming ratio, is the urbanization of the city.

Figure 4 shows the change in population density in Bangkok depending on the distance from the city center (Murakami et al., 2005). The population density of the area more than $5 \mathrm{~km}$ from the center increased with time since 1970s, though the density decreased from 1990 to 1998 inside the $5 \mathrm{~km}$ area from the center. Unfortunately, no such data exists before 1970s, however the trend of city expansion may be assumed to be the same as a first order approximation.

The depth of minimum subsurface temperature in the profile depends on the magnitude of surface warming (Taniguchi et al., 2005). Therefore, the depth of minimum temperature can be used as an indicator of the magnitude of surface warming including heat island effect due to urbanization. In Bangkok, some boreholes show minimum temperature at the surface, therefore the depth by $0.1^{\circ} \mathrm{C}$ apart from the steady gradient is used as an indicator of surface warming instead of minimum subsurface temperature. The relationships between the depth apart by $0.1^{\circ} \mathrm{C}$ from the steady gradient and the distance from the city center are shown in Fig. 5. As can be seen from Fig. 5,
2, 831-846, 2006

Anthropogenic effects

M. Taniguchi

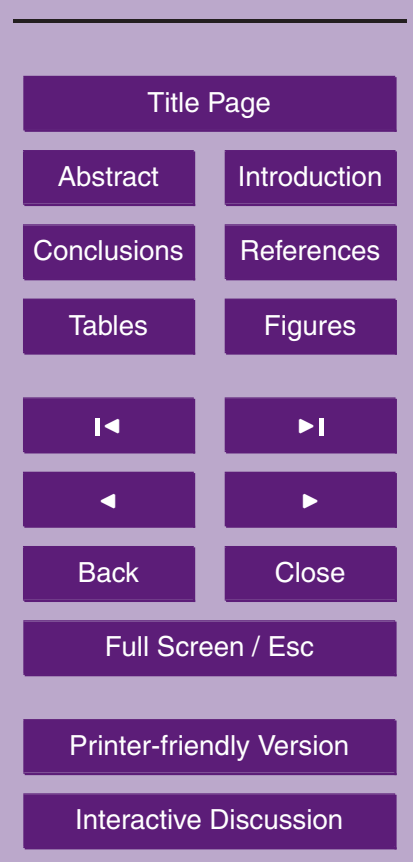


the depth decreases with the distance from the city center, which shows that surface warming is larger near the center than in the surrounding area due to the heat island effect caused by urbanization.

\section{Development of the city and subsurface temperature}

5 In order to analyze the temperature-depth profiles, calculations of subsurface temperature have been made. Carslaw and Jaeger (1959) obtained the analytical solution for subsurface temperature using a one-dimensional heat conduction-advection equation under the condition of a linear increase in surface temperature as

$$
\begin{aligned}
& T(z, t)=T_{0}+a(z-U t)+\{(b+a U) / 2 U\} \\
& \cdot\left[(z+U t) e^{U z / k} \cdot \operatorname{erfc}\left\{(z+U t) / 2(k t)^{1 / 2}\right\}\right. \\
& \left.+(U t-z) \cdot \operatorname{erfc}\left\{(z-U t) / 2(k t)^{1 / 2}\right\}\right]
\end{aligned}
$$

10 where $b$ is the rate of increase in surface temperature, $t$ is the time after semiequilibrium condition (Taniguchi et al., 1999), $T_{0}$ is the surface temperature, $T_{G}$ is the general geothermal gradient, and $U=v c_{0} \rho_{0} / c \rho$ in which $v$ is the vertical groundwater flux (Darcy's velocity), $c_{0} \rho_{0}$ is the heat capacity of the water and $c \rho$ is the heat capacity of the aquifer. The modeling is limited for semi-infinite layers with only vertical conduction and convection. Setting parameters as $T_{0}=28.2^{\circ} \mathrm{C}, k=6.0 \times 10^{-7} \mathrm{~m}^{2} \mathrm{~s}^{-1}, T_{G}=0.04$ ${ }^{\circ} \mathrm{C} / \mathrm{m}$, and $U=0.0001 \mathrm{~m} / \mathrm{s}$ (without groundwater flow), temperature-depth profiles are computed using (1).

Scenarios of surface warming for the calculations are shown in Fig. 6 . In the three scenarios $A, B$, and $C$, the increase in surface warming at the city center is assumed to be $1.6^{\circ} \mathrm{C}$ during the last 50 years (Fig. 3a). As can be seen from the population change from the city center to the suburb (Fig. 4), the population density in Bangkok decreases exponentially with the distance from the city center. Although additional heat due to urbanization does not exactly correspond to the population, the change in population
2, 831-846, 2006

Anthropogenic effects

M. Taniguchi

Title Page

Abstract Introduction

Conclusions

References

Tables

Figures

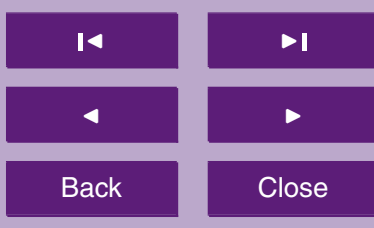

Full Screen / Esc

Printer-friendly Version

Interactive Discussion 
density may be used as a first order factor of the heat island effect. Therefore, the increase in air temperature can be assumed to be decreasing exponentially from the city center as shown in Fig. 6 . In the scenarios, the increase in surface temperature is assumed to be $T=1.6 \mathrm{e}^{-0.01 x}$ (where $\mathrm{x}$ is the distance from the city center) for scenario $5 \mathrm{~A}, \mathrm{~T}=1.6 \mathrm{e}^{-0.02 x}$ for scenario $\mathrm{B}, 1.6 \mathrm{e}^{-0.05 x}$ for scenario $C$, respectively.

The results of calculations under the scenarios $A, B$, and $C$ are shown in Fig. 7. As can be seen from Fig. 7, the depth apart by $0.1^{\circ} \mathrm{C}$ from the steady thermal gradient decreases with the distance from the city center. Comparison between observed and calculated relationships shows that scenario B describes the most favorable agree10 ment.

To separate the surface warming effects into global warming effect and heat island effect due to urbanization, the rate of global warming is assumed to be $0.3^{\circ} \mathrm{C} / 50$ years (Hansen and Lebendeff, 1987; Huang et al., 2000). According to scenario B, the location with increase in air temperature by $0.3^{\circ} \mathrm{C} / 50$ years is about $80 \mathrm{~km}$ from the city

center. Therefore, our analyses of subsurface temperature without air temperature data shows that heat island effect due to urbanization reaches up to $80 \mathrm{~km}$.

\section{Conclusions}

Analyses of subsurface temperature in Bangkok have been made to evaluate the effects of heat island due to urbanization. The conclusions of this study are summarized as follows;

1. The magnitude of surface warming evaluated from subsurface temperature at Bangkok was $1.7^{\circ} \mathrm{C}$ which agreed with meteorological data during the last 50 years.

2. The depth apart from the regional geothermal gradient, which is an indicator of the magnitude of surface warming, is deeper in the center of the city than in the suburb areas of Bangkok.

Anthropogenic effects

M. Taniguchi

\section{Title Page}

Abstract Introduction

Conclusions References

Tables Figures

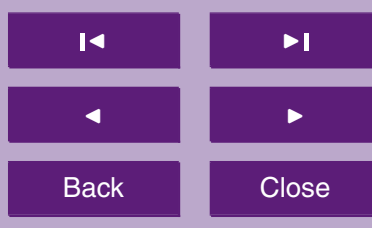

Full Screen / Esc

Printer-friendly Version

Interactive Discussion 
3. Analyses of subsurface temperature depending on the distance from the city center have been done with different scenarios of surface warming. The results show that the expansion of urbanization in Bangkok reaches up to $80 \mathrm{~km}$ from the city center.

5 Acknowledgements. This research was financially supported in part by the Research Institute for Humanity and Nature (RIHN) project 2-4 "Human impacts on urban subsurface environment".

\section{References}

Beck, A. E.: Precision logging of temperature gradients and the extraction of past climate, 10 Techtonophys., 83, 1-11, 1982.

Beltrami, H., Chapman, D. S., Archambault, S., and Bergeron, Y.: Reconstruction of high resolution ground temperature histories combining dendrochronological and geothermal data, Earth Planet. Sci. Lett., 136, 437-445, 1995.

Birch, F.: The effects of pleistocene climatic variations upon geothermal gradients, Am. J. Sci., 246, 729-760, 1948.

Bodri, L. and Cermak, V.: Last 250 years climate reconstruction inferred from geothermal measurements in the Czech Republic, in: Heat Flow and Structure of the Lithosphere - IV, edited by: Cermak, V., Tectonophysics, 291, 252-261, 1998.

Bodri, L. and Cermak, V.: Climate changes of the last millennium inferred from borehole temperatures: regional patterns of climate changes in the Czech Republic - Part III, Global Planet. Change, 21(4), 225-235, 1999.

Carslaw, H. S. and Jaeger, J. C.: Conduction of Heat in Solids, 2nd Ed., Oxford University Press, 510p, 1959.

Chapman, D. S. and Harris, R. N.: Repeat temperature measurements in borehole GC-1, northwestern Utah: Towards isolating a climate-change signal in borehole temperature profiles, Geophys. Res. Lett., 20, 1891-1894, 1993.

Domenico, P. A. and Palciauskas, V. V.: Theoretical analysis of forced convective heat transfer in regional ground-water flow, Geol. Soc. Am. Bull., 84, 3803-3813, 1973.
2, 831-846, 2006

Anthropogenic effects

M. Taniguchi

Title Page

Abstract

Introduction

Conclusions

References

Tables

Figures

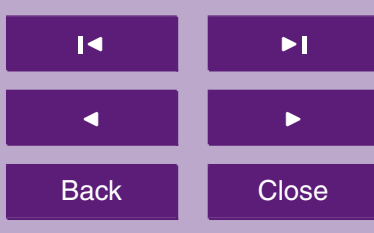

Full Screen / Esc

Printer-friendly Version

Interactive Discussion 
Ferguson G. and Woodbury, A. D.: Subsurface heat flow in an urban environment, J. Geophys. Res., 109, B02402, doi:10.1029/2003JB002715, 2004.

Hansen, J. and Lebedeff, S.: Global trends of measured surface air temperature, J. Geophys. Res., 92, 13345-13372, 1987.

5 Harris, R. N. and Chapman, S. D.: Borehole temperatures and a baseline for 20th-century global warming estimates, Science, 275, 1618-1621, 1997.

Huang, S., Pollack, H. N., and Shen, P. Y.: Temperature trends over the past five centuries reconstructed from borehole temperatures, Nature, 403, 756-758, 2000.

Lachenbruch, A. H. and Marshall, B. V.: Changing climate: Geothermal evidence from permafrost in the Alaskan Arctic, Science, 234, 689-696, 1986.

Murakami, A., Zain, A. M., Takeuchi, K., Tsunekawa, A., and Yokota, S.: Trends in urbanization and patterns of land use in the Asian mega cities Jakarta, Bangkok, and Metro Manila, Landscape and Urban Planning, 70, 251-259, 2005.

Okubo, Y., Kim, H.-C., Uchida, Y., Goto, S., and Safanda, J.: Borehole data and Climate reconstruction in Korea, 2003 Korea-Japan Joint Seminar on Geophysical Techniques for Geothermal Exploration and Subsurface Imaging, Proceedings, 58-63, September 22-26, 2003.

Pollack, H. N., Huang, S., and Shen, P. Y.: Climate Change Record in Subsurface Temperatures: A Global Perspective, Science, 282, 279-281, 1998.

Sanford, W. E. and Buapeng, S.: Assesment of a groundwater flow model of the Bangkok basin, Thailand, using carbon-14-based ages and paleohydrology, Hydrogeol. J., 4, 26-40, 1996.

Taniguchi, M., Shimada, J., Tanaka, T., Kayane, I., Sakura, Y., Shimano, Y., Dapaah-Siakwan, S., and Kawashima, S.: Disturbances of temperature-depth profiles due to surface climatechange and subsurface water flow: (1) An effect of linear increase in surface temperature caused by global warming and urbanization in the Tokyo metropolitan area, Japan, Water Resour. Res., 35, 1507-1517, 1999.

Taniguchi, M., Shimada, J., and Uemura, T.: Transient effects of surface temperature and groundwater flow on subsurface temperature in Kumamoto Plain, Japan, Phys. Chem. Earth, 28, 477-486, 2003.

30 Taniguchi, M. and Uemura T.: Effects of urbanization and groundwater flow on the subsurface temperature in Osaka, Japan, Phys. Earth Planet. Interior, 152, 305-313, 2005.

2, 831-846, 2006

Anthropogenic effects

M. Taniguchi

Title Page

Abstract Introduction

Conclusions

References

Tables

Figures

I

14

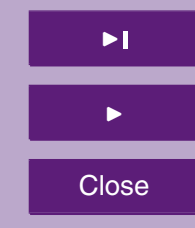

Full Screen / Esc

Printer-friendly Version

Interactive Discussion 


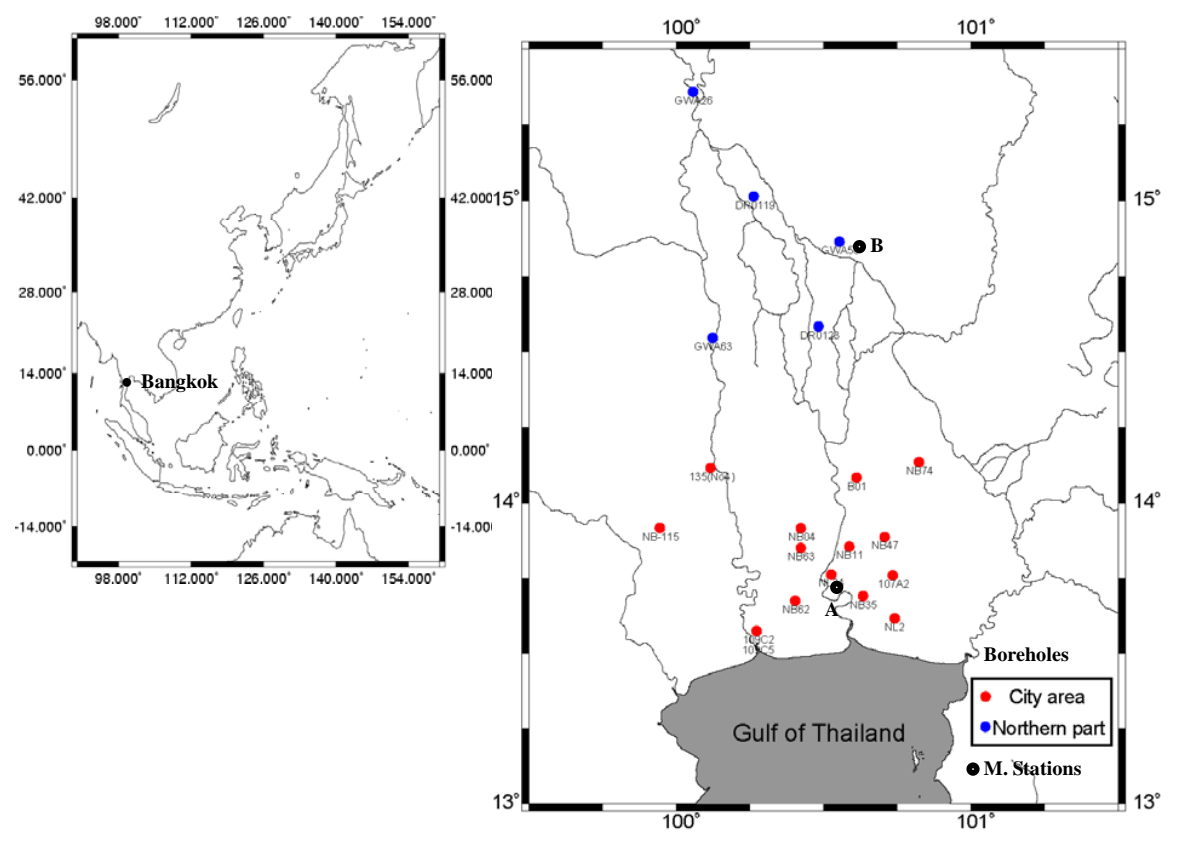

\section{Anthropogenic effects}

M. Taniguchi

\begin{tabular}{|c|c|}
\hline \multicolumn{2}{|c|}{ Title Page } \\
\hline Abstract & Introduction \\
\hline Conclusions & References \\
\hline Tables & Figures \\
\hline I4 & \\
\hline 4 & $\bullet$ \\
\hline Back & Close \\
\hline Full Screen / Esc
\end{tabular}

Fig. 1. Locations of the study area and observation boreholes. 
(a)

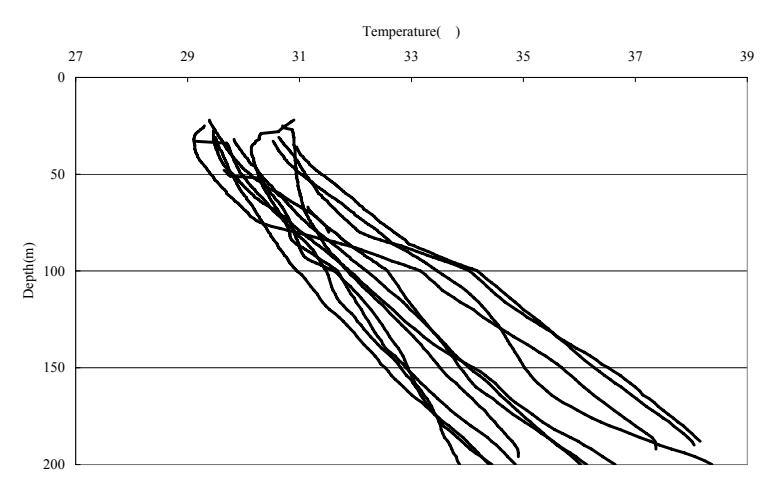

2, 831-846, 2006

\section{Anthropogenic effects}

M. Taniguchi

(b)

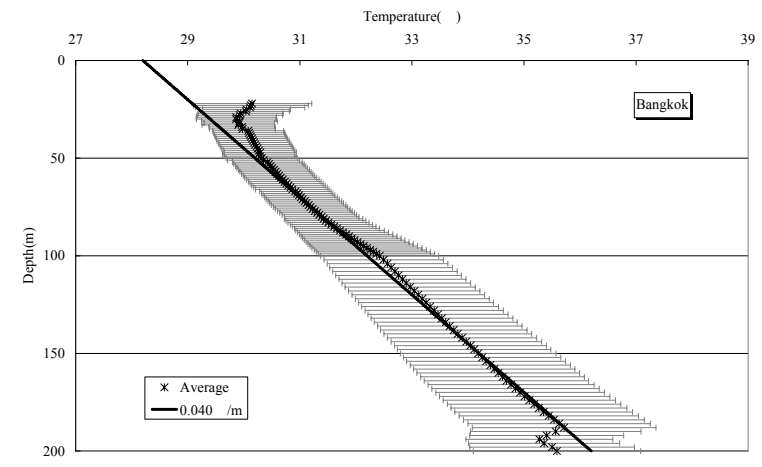

\begin{tabular}{|c|c|}
\hline \multicolumn{2}{|c|}{ Title Page } \\
\hline Abstract & Introduction \\
\hline Conclusions & References \\
\hline Tables & Figures \\
\hline I4 & $\bullet \mathbf{I}$ \\
\hline 4 & $\bullet$ \\
\hline Back & Close \\
\hline Full Screen / Esc
\end{tabular}

Printer-friendly Version

Interactive Discussion

Fig. 2. Observed temperature-depth profiles (top), and average and standard deviation of profiles with thermal gradient (bottom) in Bangkok. 


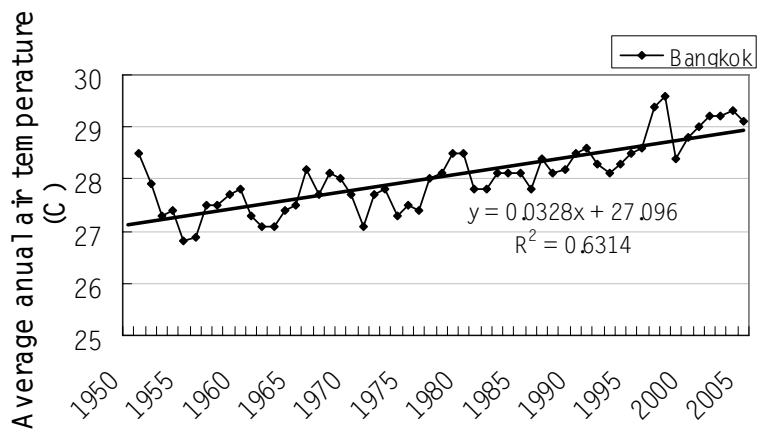

(b)

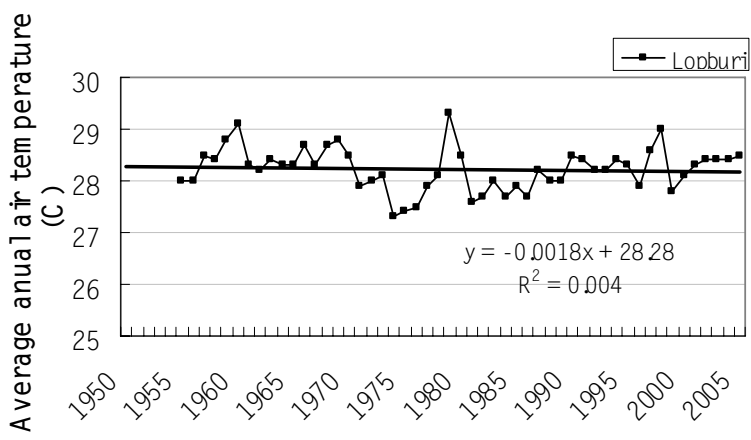

Fig. 3. Changes of air temperature at $A$ (city center) and $B(120 \mathrm{~km}$ north of the city center).
2, 831-846, 2006

Anthropogenic effects

M. Taniguchi

Title Page

Abstract

Introduction

Conclusions

References

Tables

Figures

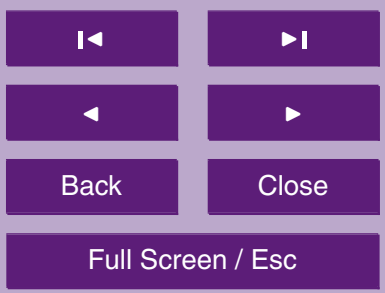

Printer-friendly Version

Interactive Discussion 
2, 831-846, 2006

Population density

(persons/ha)

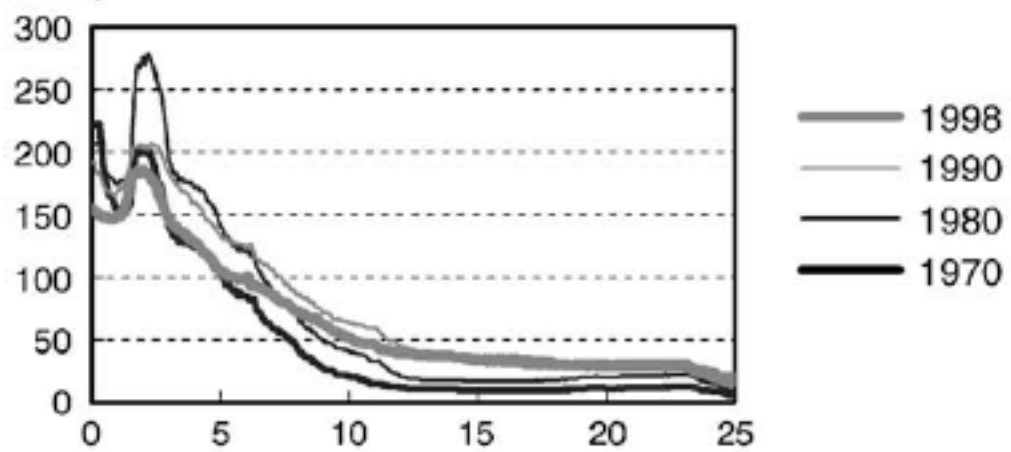

Distance from the city center $(\mathrm{km})$
Anthropogenic effects

M. Taniguchi

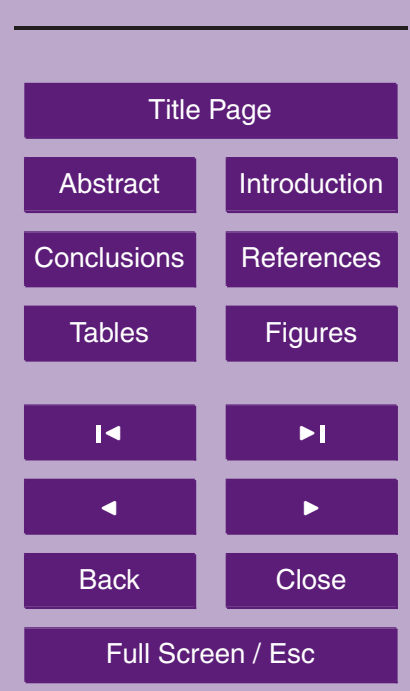

Printer-friendly Version

Interactive Discussion 
2, 831-846, 2006

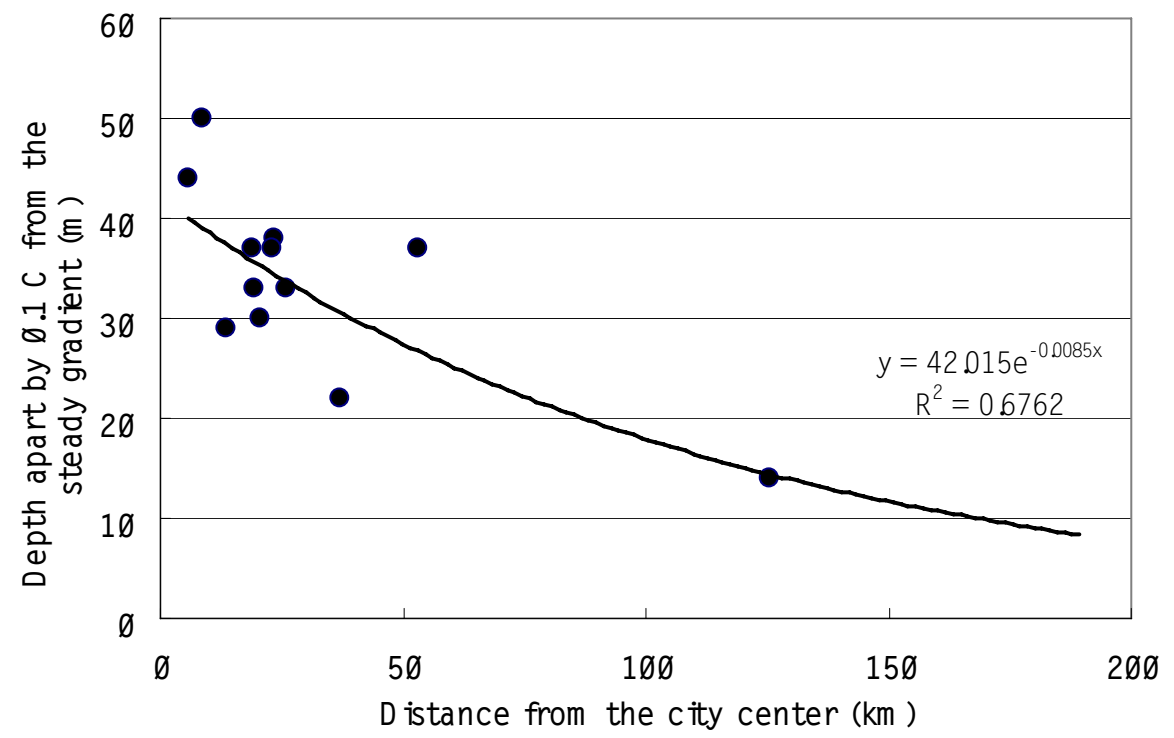

Anthropogenic effects

M. Taniguchi

\begin{tabular}{|c|c|}
\hline \multicolumn{2}{|c|}{ Title Page } \\
\hline Abstract & Introduction \\
\hline Conclusions & References \\
\hline Tables & Figures \\
\hline I4 & \\
\hline 4 & $\triangleright$ \\
\hline Back & Close \\
\hline Full Screen / Esc
\end{tabular}

Fig. 5. Observed relationships between the depth apart by $0.1^{\circ} \mathrm{C}$ from the steady thermal gradient and the distance from the city center.

Printer-friendly Version

Interactive Discussion 
2, 831-846, 2006

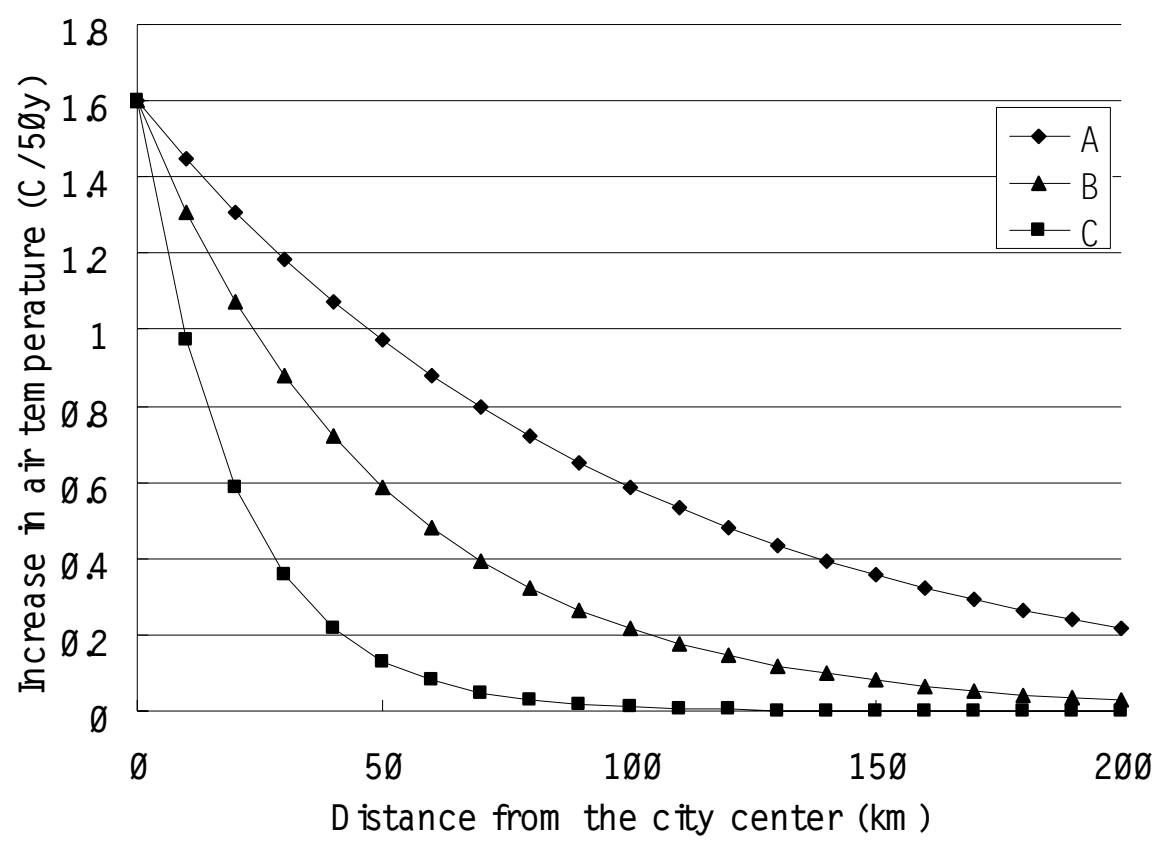

\section{Anthropogenic effects}

M. Taniguchi

\begin{tabular}{|c|c|}
\hline \multicolumn{2}{|c|}{ Title Page } \\
\hline Abstract & Introduction \\
\hline Conclusions & References \\
\hline Tables & Figures \\
\hline I4 & \multicolumn{1}{|c|}{} \\
\hline 4 & $\triangleright$ \\
\hline Back & Close \\
\hline Full Screen / Esc
\end{tabular}

Fig. 6. Scenarios of surface warming depending on the distance from the city center.

Printer-friendly Version

Interactive Discussion 


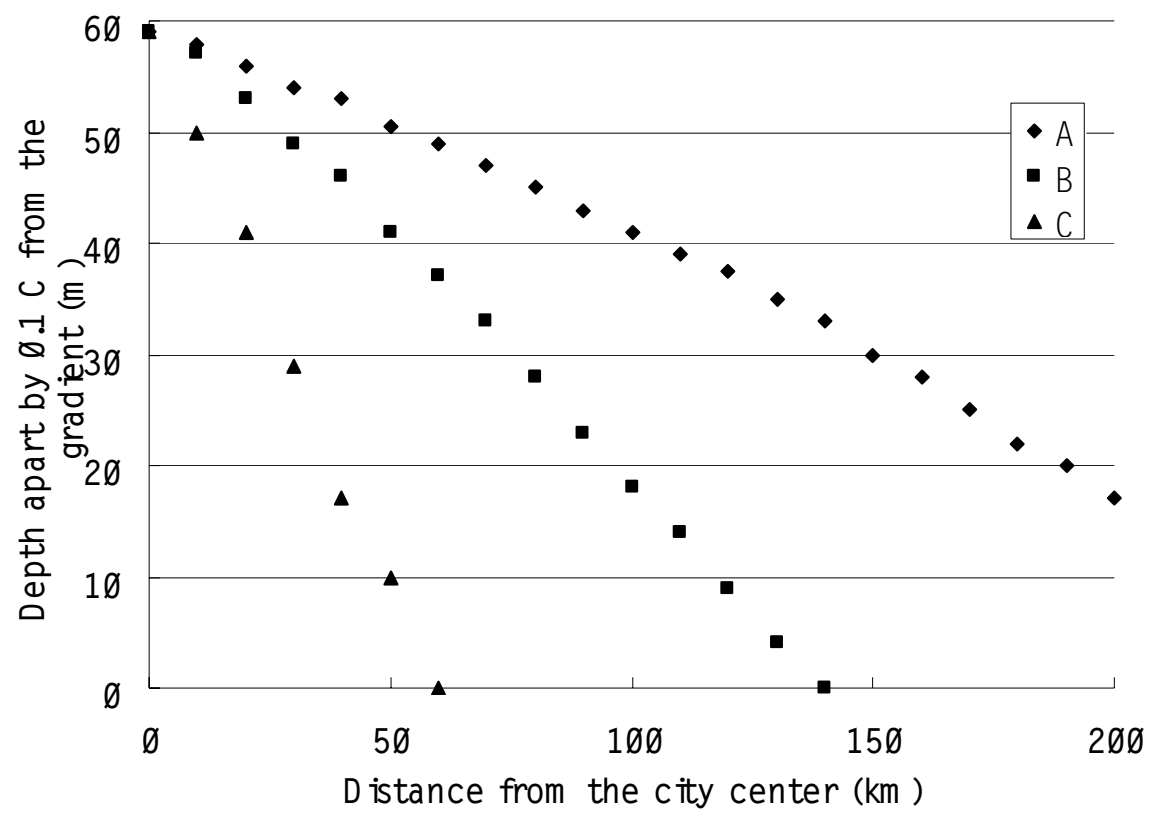

2, 831-846, 2006

Anthropogenic effects

M. Taniguchi

\begin{tabular}{|c|c|}
\hline \multicolumn{2}{|c|}{ Title Page } \\
\hline Abstract & Introduction \\
\hline Conclusions & References \\
\hline Tables & Figures \\
\hline I4 & $\bullet \mathbf{I}$ \\
\hline 4 & $\triangleright$ \\
\hline Back & Close \\
\hline Full Screen / Esc
\end{tabular}

Fig. 7. Calculated relationships between the depth apart by $0.1^{\circ} \mathrm{C}$ from the steady thermal gradient and the distance from the city center.

Printer-friendly Version

Interactive Discussion 